Dept. of Theriogenology

Faculty of Vet. Med., Assiut University

Head of Dept. Prof. Dr. A.M.Osman

\title{
IN VITRO BUFFALO SPERM CAPACITATION WITH SPECIAL ATTENTION TO ACROSOME REACTION AND OOCYTE PENETRATION TEST \\ (With 5 Table and 3 Figures)
}

\author{
By \\ S.H.SHEHATA \\ (Received at 23/12/1997)
}

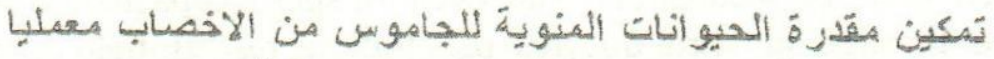

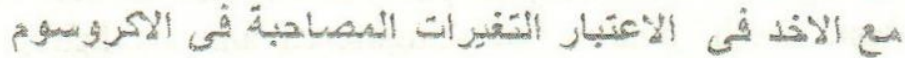

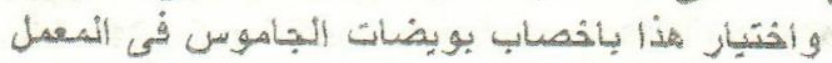

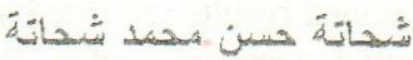

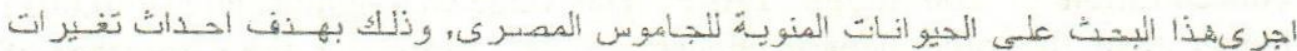

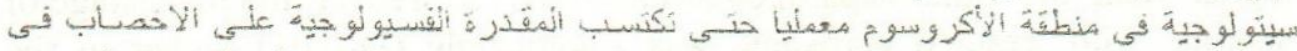

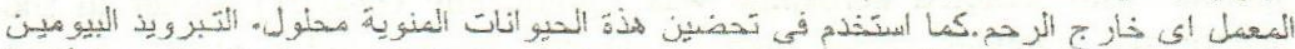

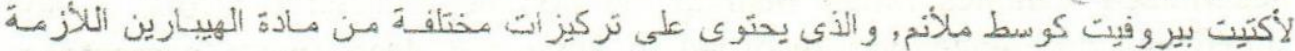

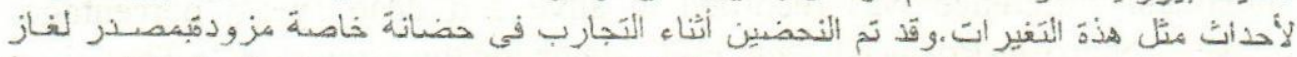

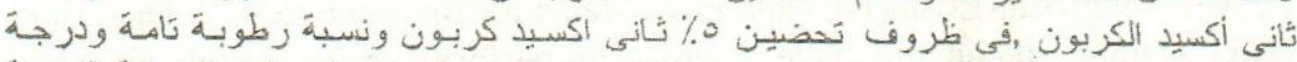

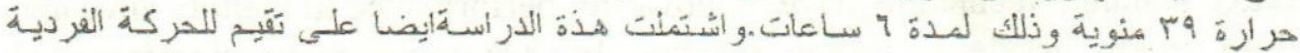

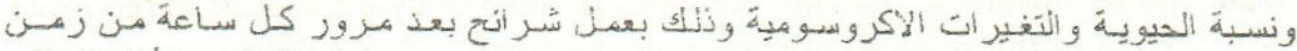

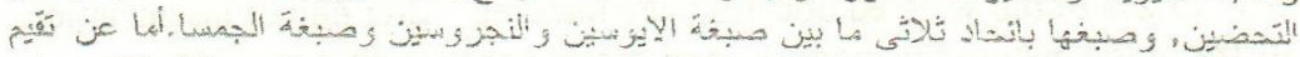

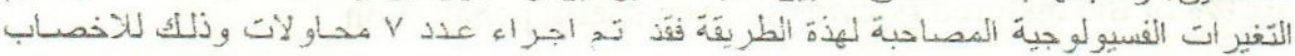

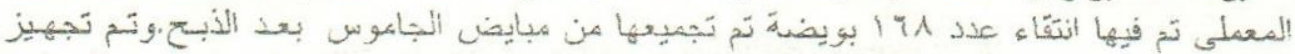

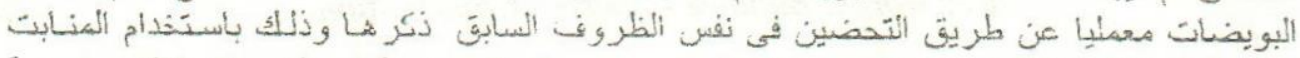

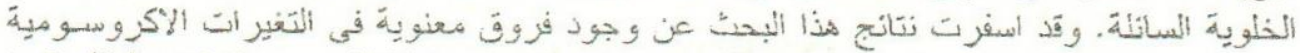

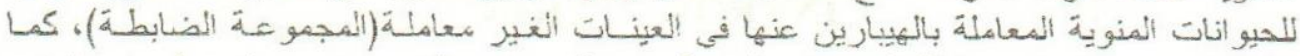

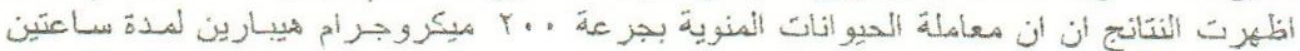

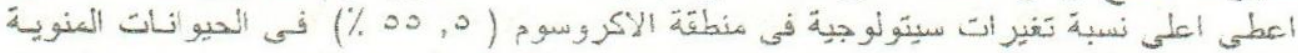

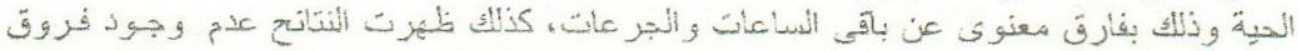




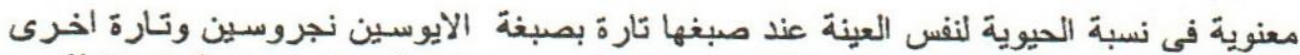

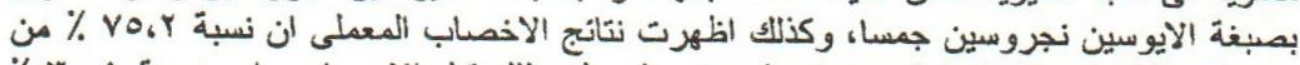

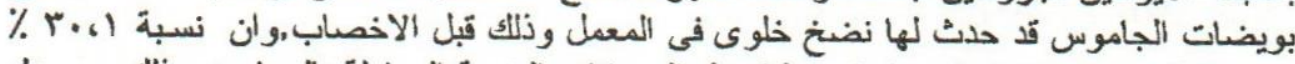

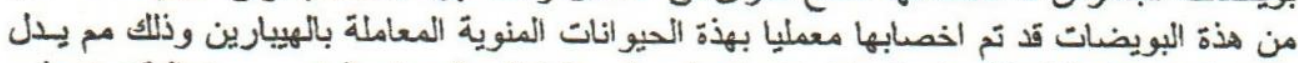

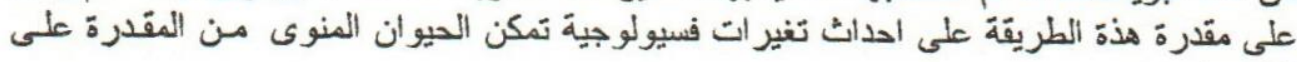

\section{SUMMARY}

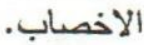

In vitro Buffalo sperm capacitation and assessment of acrosome reaction by using Nigrosin-Eosin-Gemisa(NEG) staining technique were performed. Sperm capacitation was done by TALP capacitation media with different concentrations of heparin. During capacitation process the environmental condition was $5 \% \mathrm{Co}_{2}$ with maximum humidity at $39^{\circ} \mathrm{C}$ as long as $6 \mathrm{~h}$ incubation period. Acrosome reaction, livability and motility was evaluated after each hour of incubation. The event of sperm capacitation was finally evaluated through in vitro oocytes penetration test. Buffalo oocytes were collected from fresh ovaries of slaughtered animals, then prepared and matured in vitro in the same incubation condition for $24 \mathrm{~h}$. Minimal Essential tissue culture media (MEM) with $15 \%$ follicular fluid was used as a maturation media. The obtained results recorded a maximum value of $55.5 \%$ for alive sperm with reacted acrosome after $2 \mathrm{~h}$ incubation with heparin concentration of $200 \mu \mathrm{g} / \mathrm{ml}$ TALP. This value was significantly $(\mathrm{P}<0.001)$ higher than the other heparin concentrations. Moreover, the percentage of sperms with reacted acrosome was significantly $(\mathrm{P}<0.01)$ higher in the heparinized samples rather than in the non heparinized controls. A non significant difference was recorded in alive and dead sperm percentages between Nigrosin-Eosin(NE) and NEG stains for the same sample.Therefore, NEG staining technique have a powerful performance to identify alive and dead sperm beside acrosome reaction. In vitro oocyte maturation recorded that $75.2 \%$ of the selected oocytes were matured. After $48 \mathrm{~h}$ of insemination, $30.1 \%$ of the matured oocytes showed sperm penetration..

Key words: Buffaloe - Sperm - Capacitation

\section{INTRODUCTION}

It is now over than four decades since Austin (1951) who reported that spermatozoa needed a period of residence in the female genital tract 
before they were able to penetrate an ovulated egg. During the last decade progress has been made in developing bovine in vitro fertilization systems using matured oocytes (Ijaz and Hunter, 1992). Such systems have the potential for yielding embryos for embryo transfer and for genetic manipulation. Therefore, our needs increased to perform an in vitro sperm capacitation and fertilization systems, especially for buffaloes as it is an important local and world wide dairy breed. Many changes have been described as taking place in sperm cells said to be "capacitated" (CohenDayag and Eisenbach, 1994). The majority of these changes appears to involve alterations in plasma-membrane structure and function (Harrison, 1996). Acrosome exocytosis (acrosome reaction) and expression of vigorous flexible flagella movement (hyperactivated motility) are the two sperm functions appears essential to fertilization (Bedford, 1994). The acrosome reaction releases or exposes the acrosome's content of hydrolytic enzymes, which are believed to lyse zona pellucida components and enable penetration (Harrison, 1996).

In vitro, a lot of sperm capacitation and acrosome reaction (AR) inducers has been used. These inducers varies between enzymes, hormones and chemicals, that has been used in different doses and in different incubation times (Tarin and Alan,1994). The most commonly used substances for in vitro sperm capacitation and AR inducers are heparin and caffeine (Leclerec et al., 1989; and Leclerec et al., 1992).Moreover, Calcium ionophore A 23187 (Cummins, et al., 1991), 17 $\beta$-oestradiol (Chan et al., 1993), $\beta$-amino acids (Chan, 1985) and theophylline (Perreault and Rogers, 1982) were also used in sperm capacitation and AR in human.

To distinguish acrosomal reaction in the alive sperm, several supervital staining techniques have been developed. A triple staining technique with trypan blue using Bismark brown and rose Bengal has been used by Talbot and Chacon (1981). Moreover, Giemsa stain (Watson, 1975), Naphtha yellows and erythrosin B (Bryan and Akruk, 1977), and the Fix vital stain (Deleeuw et al., 1991) were used to distinguish AR. Tamuli and Watson (1994) demonstrated a simple and reliable staining technique in which nigrosin-eosin (NE) and the Giemsa stains were combined in nigrosineosin-Gimesa (NEG) stain technique.

Since sperm capacitation is a bio-physiological process, Ijaz and Hunter (1989 and 1992) reported that sperm capacitation in bull should be measured more accurately by the ability of the sperm to penetrate bovine oocytes matured in vitro. Unfortunately buffalo sperm capacitation and IVF have a little attention all over the world. In Egypt El-Amrawi and Nemetallah 
(1991) had a trial for buffalo sperm capacitation in vivo. However, Omaima et al., (1996) studied the effect of heparin and caffeine on capacitation of buffalo and cattle spermatozoa. So, the present study have three main objectives. The first is to study the effect of heparin, its optimum dose and optimum incubation hours for sperm capacitation. The second is to evaluate the performance of a simple staining technique using the NEG stain to asses acrosomal changes and livability of capacitated sperms. The third is to evaluate capacitation by determining the ability of treated sperms to penetrate the buffalo oocytes matured in vitro.

\section{MATERIALS and METHODS}

\section{Semen collection and sperm capacitation:}

Semen was collected by the artificial vagina from three locally bred buffalo bulls. Ejaculates were transported to the laboratory in an insulated ice box within $10 \mathrm{~min}$. of collection. All samples were evaluated immediately for motility and sperm cell concentration. Ejaculates over $70 \%$ motility were used for sperm capacitation The process of capacitation was done according to the recent procedure of Gordon (1994) in cattle.Moreover, to get better results in buffalo, the centrifugation rates were decreased to $300 \times \mathrm{xg}(1500 \mathrm{rpm})$ during sperm wash. In conical sterile microfuge tube, 0.5 $\mathrm{ml}$ of washed semen was extended with equal volume of the prepared capacitation media (TALP). This media contain 100,200,300 and $400 \mu \mathrm{g}$ heparin $/ \mathrm{ml}$ media . Another non heparinized tube used as a control. All tubes were incubated at $39^{\circ} \mathrm{C}$ in $5 \% \mathrm{CO}_{2}$ in air and $100 \%$ relative humidity in $\mathrm{CO}_{2}$ incubator. After every hour of incubation and up to $6 \mathrm{~h}$., semen samples were smeared for staining and microscopical evaluation.

\section{Staining Technique:}

The staining technique applied in the present study was performed according to the modified technique of Tamuli and Watson(1994). They used a combination between nigrosin-eosin-Giemsa (NEG) stains to differentiat the alive and dead sperms as well as the reacted and non reacted acrosomes. The evaluation of semen smears was carried out by counting 100 sperm cells from each slide under the microscope fitted with a bright-field oil immersion lens at a magnification of $1000 \mathrm{X}$.

Assessment of sperm penetration:

Buffalo oocytes from the ovaries of slaughtered animals were allowed to in vitro maturation at $38^{\circ} \mathrm{C}$ for $24 \mathrm{~h}$ after Ijaz and Hunter (1992). A tissue 
culture media " Minimum Essential Media (MEM)" with 15\% buffalo follicular fluid was used as a maturation media (Moriyama et al., 1996). Fertilization was carried in a modified tyrodes solution as a fertilization media (Gordon, 1994). From 2-3 microdroplets (each of $100 \mu \mathrm{l}$ ) of the media were prepared in sterile $3 \mathrm{~cm}$ falcon petri dish. Each droplet was covered with a single drop of sterile paraffin oil. The dish was placed in $5 \%$ $\mathrm{CO}_{2}$ at $38-39^{\circ} \mathrm{C}$ at least one hour for equilibration. The matured denuded oocytes were transferred to the fertilization microdroplets with 5-10 oocytes per each droplet. Insemination was done by adding 5-10 $\mu 1$ of the already prepared capcitated sperm $\left(2 \times 10^{7}\right.$ sperm $\left./ \mathrm{ml}\right)$ suspension to the microdroplets. Sperm and oocytes were cocultured for $8 \mathrm{~h}$ at the same mentioned incubation condition. All oocytes were removed and washed twice in MEM- and transferred to fresh fertilization droplet. After $24 \mathrm{~h}$. of culture, the oocytes were transfered to another fresh MEM. After $48 \mathrm{~h}$, they were removed from the media, placed on a slide, flattened with a cover-slip, fixed in ethanol acetic acid and stained with Gemisa stain. The oocytes were examined microscopically at $400 \mathrm{X}$. The presence of swollen sperm head with its dissociated tail with one or more pronuclei in the cytoplasm, indicates ovum penetration.

\section{Experiment 1:}

A total number of 21 ejaculates( 7 per bull)were taken for sperm capacitation. To get enough volume of washed semen samples, each 2 ejaculates were pooled together randomly. A total of 10 trials were performed from these samples for sperm capacitation and staining techniques.

\section{Experiment 2:}

Out of the results taken from experiment 1, the optimum dose of heparin and incubation hours was applied here to get the best capacetation rate. From each buffalo bull, further 5 ejaculates were collected and subjected for the above mentioned capacitation procedures separately with a total of 15 trials. The sperm motility for each sample was evaluated just before incubation and at each hour during incubation till $6 \mathrm{~h}$. To evaluate the efficiency of NEG stain another smears from the same sample were prepared and stained with NE for comparative study of alive and dead sperms.

\section{Experiment 3:}

Seven trials for buffalo oocytes penetration tests using capacitated sperm were performed in this experiment. A total number of 168 oocytes were matured in vitro and insemination of these oocytes were done by using 
the buffalo semen with best parameters after capacitation process (experiment 2). The presumed fertilized oocyte complexes were cultured at $37^{\circ} \mathrm{C}$ for $48 \mathrm{~h}$ and evaluated for penetration.

\section{Statistical Analysis:}

Analysis of variance by General Linear Models Procedure for alive and dead sperm (either reacted or non reacted) as dependent variables for heparin doses, incubation times, stains and bulls were performed (SAS, 1987). Means that were different $(\mathrm{P}<0.05)$ were tested using Duncan's multiple range test.

\section{RESULTS}

\section{Expirment 1:}

Variable percentages were recorded for sperm livability and AR with regard to hours of incubation and heparin concenterations (Table1). Applying the analysis of variance by General Linear Model procedur (GLM) for alive and dead sperms with either reacted or non reacted acrosomes, (Table 2) showed that best result (significantly higher $>0.001$ ) occurred at $2 \mathrm{~h}$ incubation period with a heparin dose of $200 \mu \mathrm{g} / \mathrm{ml} \mathrm{TALP}$. It is evident from fig. 1 that the post acrosomal regions in alive sperms appeared slightly pink or transparent while in dead sperms it appeared purple. The acrosomal condition could be evaluated because it is deeply stained purple in colour. The reacted sperm cells apeared without acrosome or the acrosomal area is faint in colour. In comparison to the control group a significant differences $(p>0.01)$ were recorded for the livability in both reacted and non reacted sperms.

\section{Experiment 2:}

Out of table 3 , it is clear that sperm motlity decreased significantly after 3 hour of incubation in washed samples. Moreover, the spermatozoa of bull no. 3 have abetter resistance for washing. The effect of heparin (200 $\mu \mathrm{g} / \mathrm{ml}$ ) on sperm viability and acrosome reaction showed a marked and significant improvement in bull no. 3 in comparison to the other two bulls (table 4). The performance of NEG stain to determine sperm viability was studied by comparing its results with those stained with NE taken from the same samples. A non significant differences were recorded between alive and dead sperms. A least square means values $(n=60)$ that recorded for alive sperms were $79.96 \pm 0.23$ and $79.70 \pm 0.32$ for NEG and NE stain respectively. While a least square mean values recorded for dead sperms 
were $20.5 \pm 0.41$ and $20.2 \pm 0.41$ for NEG and NE respectively. Meaning that no differences could be traced between the results of both stains.

\section{Experiment 3:}

The results of in vitro oocytes maturation and sperm penetration tests are presented in table 5 . After $24 \mathrm{~h}$ incubation $73.2 \%$ of the selected oocytes were matured. This maturation was indincated by the presence of the female pronuclei and the condensation of the chromatin material of the nucleus (Fig.3A ). After 24-48 h from insemination, the over all percentage of $30.1 \%$ of oocytes showed zona penetration. This penetration event was indicated by the presence of sperm head in the cytoplasm and or the presence of the 2 nd polor body or cleaved ovum (Fig. 3b). The obtained penetration rates indicate a succesfull in vitro sperm capacitation.

\section{DISCUSSION}

The results of the present study showed that heparin can capacitate buffalo sperm in a dose and incubation times dependent manner. The highest level of acrosome reaction (as an indication for sperm capacitation) was recorded after $2 \mathrm{~h}$ incubation when semen treated with a concentration of 200 $\mu \mathrm{g}$ heparin /ml TALP media. Lu (1990) had indicated that in bull semen the optimum dose of heparin is $100 \mu \mathrm{g} / \mathrm{ml}$, however, this dose was ten folds that recommended by Parrish et al. (1986). The avialable leterature reported a wide range in heparin concentrations for sperm capacitation in bull. Shi (1991) cited a range of $2 \mu \mathrm{g} / \mathrm{ml}$ to $486 \mu \mathrm{g} / \mathrm{ml}$ heparin in cattle. Moreover, in buffaloes Totey et al., (1993) recomended that sperm capacitation is dependent on heparin doses. Concerning the incubation period, Parrish et al. (1984) recommeded $4 \mathrm{~h}$ incubation period for freshly collected bull sperm and $0.5 \mathrm{~h}$ or less for frozen-thawed semen. In this respect, Wheeler and Seidel (1986) concluded that fresh semen requires a longer capacition period than frozen.

The results of the present work recorded a percentages of $28.1,23.8$ and 22.8 for alive reacted sperms after two hour incubation for the examined three buffalo bulls when treated individually. Moreover, an increase in the percentages of dead sperms were recorded after incubation. Similarly and Yoon et al. (1996) recorded a highest mean values of $23.2 \%$ for reacted and $26.6 \%$ for non reacted alive sperms after $2 \mathrm{~h}$ incubation in Korean native cattle sperm. Moreover, the same authors recorded an increase in the percentages of reacted dead sperms after capacitation and AR. For the same concept, Harrison (1996) suggested that capacitation is not a limited process 
that culminates in a defined cellular state, but rather a continuing process of positive destabilization that leads eventually to cell death.

The biochemical events which occur during capacitation are unclear (Leclerc, et al., 1992), however, the importance of extracellular $\mathrm{Ca}^{2+}$ and intracellular $\mathrm{Ca}^{2+}$ was observed years ago (Yanagimachi and Usui , 1974). Jones et al. (1980) recorded that sperm cells contain large amount of Calmodulin ( $\mathrm{CaM})$, which act as an important $\mathrm{Ca}$ mediator. $\mathrm{CaM}$ regulates a large number of enzymes in various cell types and play an important role in sperm capacitation and acrosome reaction especially due to its location in the acrosomal region( Weinman $\underline{\epsilon t}$ al., 1986). The role of heparin as an inducer to sperm capacition and acrosome reaction had been discussed by several authors. Handrow et al. (1989) reported that heparin binds to bull sperms in ligand receptor manner and induces capacitation, which is related to the net $\mathrm{Ca}^{2+}$ up take. Leclerc et al. (1989) mentioned that heparin induces changes in $\mathrm{CaM}$-binding properties of specific sperm proteins. Moreover, Leclerc et al. (1992) found that heparin induces a reduction in sperm CaM concentration during capacition, and this decrease seems to be related to capacitation. The same author suggested that $\mathrm{CaM}$ is released from spermatozoa to the extracellular medium during heparin treatment.

The release of $\mathrm{CaM}$ can be facilitated by the action of proteases such as acrosin. Concerning the effect of heparin in acrosome reaction, the present study revealed a significant difference between the heparin treated semen and the control. This result is contradicted with Parrish et al. (1988) and Leclerc et al. (1992), who reported that heparin is a capacitating agent, but does not induce acrosome reaction. However, the result of this work is in agreement with Yoon et al. (1996) and Harrison (1996), who indicated that heparin could be considered as a capacitating agent and inducer to acrosome reaction.

In buffảoes, similar results were recorded by Omima et al. (1996) for the effect of heparin on sperm capacitation. But the authers evaluate capacitation only by acrosome stains and incubate for $4 \mathrm{~h}$ in water bath without $\mathrm{CO}_{2}$ atmosphere. El-Amrawi and Nemetallah (1991), recorded that buffalo sperms showed acrosomal swollen and reaction within $2 \mathrm{~h}$ when incubated in Doe uterus. These results are in agreement with the obtained results for the time of $\mathrm{AR}$ in vitro. In addition, the present data recorded an individual varation between bulls for reacted acrosomes. For this concept, Iritani et al. (1986) and Schellander et al. (1989) mentioned that sperm from different bulls can react differently to the same capacitation treatment during 
in vitro fertilization experiments. Moreover, Iqbal and Hunter (1995) found that bulls also differed in the ability of their sperm to penetrate oocytes.

Concerning the NEG staining technique, a non significant differences were reported in the percentages of alive sperms when compared with those taken from the same sample and stained with NE stain. These findings indicate the performance of NEG stain in identifing sperm viability. The obtained results were supported by Tamuali and Watson (1994) who found a little non significant increase in the percentages of alive ram sperms when stained with NE rather than NEG. Moreover, the visual distinction during microscopical examination is easily made by this stain without time consuming and reliable results could be achived. Moreover, the obtained results as well as those of Tamuali and Watson (1994) might lead to recommend the use of such staining technique to evaluate and judge the potential fertility of semen.

In respect to oocytes penetration, the present results recorded an over all mean value of $30.1 \%$ penetration rate. This percentage ranged between $10-45 \%$ in seven trials. Moreover, $73.2 \%$ of the selected oocytes showed maturation after $24 \mathrm{~h}$ incubation. Totey et al. (1993) recorded a higher maturation rates than the present results $(81.7-86.0 \%)$ in buffalo oocytes by using TCM-199 supplemented with fetal calf serum and FSH. Moreover, Totey et al. (1996) recorded $67.0 \%$ fertilization rate for buffalo oocytes. These higher percentages in maturition and fertilization rates may be due to the differences in maturation media used in the present work and that used by the aformentioned authers. Although the present results showed a lower values (10-45\%) for penetration rates, but it is still fair enough to indicate the event of a successful in vitro buffalo sperm capacitation. Simillary, Iqbal and Hunter (1995) reported that sperm penetration rates for a range 26.4 to $48.1 \%$ indicate successful capacitation of bovine sperm. Moreover, they recorded many factors that affect the ability of sperm to fertilize oocytes. These factors include bull effect, incubation temperature,type of oocyte penetration assay and capacitation system.

\section{REFERENCES}

Austin, C.R. (1951): Observation on the penetration of the sperm into the mammalian egg. Aust. J. Sci.Res. B 4, 581-596.

Bedford, J.M. (1994): The contraceptive potential of fertilization: a physiological perspective. Hum. Reprod. 9, 842-58. 
Bryan, J.H. D. and Akruk, S.R. (1977): A nophthol yellow S and erythrosin B staining procedure for use in studies of acrosome reaction of rabbit spermatozoa. Stain tech., 52: 47-51.

Chan, S.Y.W. (1985): Taurine and human spermatozoa capacitation. Cell Biol. Int. Rep.9, 127-30.

Chan, S.Y.W.; Tang, L.C.H. and Ma, H.K. (1993): Stimulation of the zonafree hamaster ova penetration efficiency by human spermatozoa after 17ß-estradiol treatment.Fertil. Steril. 39:80-4.

Cohen-Dayag, A. and Eisenbach, M. (1994): Potential assays for sperm capacitation in mammals. Am. J. Physiol. 267, 1167-76.

Cummins, J.M.; Pember, S.M.; Jequier, A.M.; Yovich, J.L. and Hartmann, P.E. (1991): A test of the human sperm acrosome reaction following ionophore challenge. Relationship to fertility and other seminal parameters. J. Androl. 12, 98-103.

Deleerw, A.M.; Den Daas, J.H.G. and Woelders, H. (1991): The fix vital method: Simltaneous determination of viability and acrosomal status of bovine spermatozoa. J. Androl. 12: 112-118.

El-Amrawi, G.A. and Nemetallah, B.R. (1991): Study on capacitation of buffalo spermatozoa. Proc. of Egyptian Soc. Amin. Reprod. Fert. 3rd annual Congress, Cairo Jan, 12-14. Page: 214-222.

Gordon, I (1994): Laboratory production of cattle embryos, textbook, 1st Ed., CAB International : 442.

Handrow, R.R; First, N.L. and Parrish, J.J. (1989): Calcium requirement and increased association with bovine sperm during capacitation by heparin. J. Exp. Zool. 252, 174-182.

Harrison, R.A.P. (1996): Capacitation mechanisms, and the role of capacitation as seen in eutherian mammals. Reprod. Fertil. Dev. 8, 581-94.

Ijaz, A. and Hunter, A.G. (1989): Evaluation of calcium-free tyrode's sperm capacitation medium for use in bovine in vitro fertilization. j. Dairy. Sci., 72: 3280-85.

Ijaz, A. and Hunter, A.G. (1992): Evaluation of a test-yolk sperm capacitation system for use in bovine in vitro fertilization. J. Dairy Sci., 75: 394.

Iqbal, N. and Hunter, A.G. (1995): Comparison of bovine sperm capacitation systems for ability of sperm to penetrate zona-free Hanster oocytes and bovine oocytes matured in vitro. J. Dairy. Sci. 78: 77-83. 
Iritani, A.; Utsumi, K.; Miyake, M. and Yamaguchi,Y. (1986): Individual variation in the in vitro fertilization ability of bull spermatozoa . Development, Growth and Defferentiation. Suppl. 28,45.

Jones, H.P.; Lenz, R.W.; Palevitz, B.A. and Cormier, M.J. (1980): Calmodulin Localization in mammalian spermatozoa. Proc. Natl. Acad. Sci. MSA 77, 2772-76.

Leclerc, P.; Langlais, J.; Lambert, R. D.; Sirard, M. A. and Chafouleas, J.

$G$. (1989): Effect of heparin on the expression of calmodulin-binding in bull spermatozoa, J. Reprod. Fert. 85, 615-622.

Leclerc, P.; Sirard, M. A.; Chafouleas, J. G. and Lambert, R. D. (1992):

Decrease in calmodulin concentrations during heparin-induced capacitation in bovine spermatozoa . J. Reprod. Fert, 94: 23-32.

$L u, K . H$. (1990): Studies related to the in vitro maturation and fertilization of ovarian oocytes in cattle. Ph.D. Thesis, National University of Ireland, Dublin.

Moriyama, A.; H.Tatemoto; N.Isob and T.Terada (1996): Effect of aging of bovine oocytes on polyspermy, male pronuclear formation and parthenogenetic activation. 8th AAAP Animal Science congress. japan, 13-18 October. Vol.2, Page : 470-471.

Omaima, M.T.; Kandil, A.S.S. ; Abdoon and R.I. El-Sheshtawy (1996):

Capacitation of buffalo and cattle spermatozoa by heparin and caffeine. Proc. Egyptian. soc. Anim. Reprod. Fert. 8th Annual Congress Cairo, 18-20, Pag. 330-37.

Parrish, J. J.; Parrish, J. L. and First, N. L. (1984): Effect of swim-up sporation and heparin pretreatment of frozen-thawed spermatozoa in vitro fertilization of bovine oocytes. Biology of Reproduction 30 (Suppl.2) 112 (Abs).

Parrish, J. J.; Susko-Parrish, J. L. ; Lebfried-Rutledge, M. L.; Clitser, E. S.; Eyestone, W. H. and First, N. L. (1986): Bovine in vitro fertilization with frozen-thawed semen. Theriogenology, 25: 591600.

Parrish, J.J. ; Susko-Parrish, J.; Winer, M.A. and First, N.L. (1988):

Capacitation of bvoine sperm by heparin. Biol. Reprod. 39, 1171-80. Perreoult, S. D. and Rogers, B. J. (1982): Relationship between fertilizing ability and cAMP in human spermatozoa. J. Androl.3, 396-401. SAS (1987): Users Guide, Statistics, Version 6 , SAS, Inst. Inc., Cary., Nc. Schellander, K. ; Brackett, B. G. ; Keefer, C. L. and Fayrer-Hosken, R.A. (1989): Testing capacitation of bull sperm with zona-free hamster ova. Anim. Reprod. Sci., 18, 95-104. 
Shi, D. S. (1921): Studies related to factors affecting the yield of bovine embryos produced by in vitro techniques. Ph.D. Thesis, National University of Ireland, Dublin.

Talbot, P. and Chacon, R. (1981): A triple stain technique for evaluating normal acrosome reaction of human sperm. J. Exp. Zool., 215: 201208.

Tamuli, M. K. and Watson, P. F. (1994): Use of a simple staining technique to distinguish acrosomal changes in the live sperm sub-population Anim. Reprod. Sci., 35: 247-254.

Tarin, J. and Alan O.T. (1994): Inducers of the acrosome reaction. Reprod. Fertil. Dev. 6: 33-6.

Totey, S. M.; Pawshe, C. H. and Singh, G. P. (1993): In vitro maturation and fertization of buffalo oocytes (Bubalis bubalis): effects of media, hormones and sera. Theriogenology, 39: 1153-1171.

Totey, S. M., M.dalivi, KBC, APPa roa, C.H. pawske, M.Taneja and R.S. Chillov (1996): Dfferential cleavage and developmental rates and their correlation of cell number and sex ratios in buffalo embryos generated in vitro. Theriogenology, 45:521-533

Watson, P. F. (1975): Use of Giemsa stain to detect changes in acrosomes of frozen ram spermatozoa. Vet. Rec., 97: 12-15.

Weinman, S.; Ores-Corton, C. ; Reinteau, D. and Puszkin, S. (1986): Immunelectron microscopic localization of calmodulin and phospholipase A2 in spermatozoa. J. Histochem. Cytochem. 34: 1171-1179.

Wheeler, M. B. and Seidel, G. E. Jr. (1986): Time course of in vitro capacitation of frozen and unfrozen bovine spermatozoa. Theriogenology, 25, 216.

Yanagimachi, R. and Usui, N. (197t): Calcium dependence of the acrosome reaction and activation of guina-pig spermatozoa. Exp. Cell. Res. 89, 191-174.

Yoon,J.T. ; Lee, K.Y. T.H.; Y.C. Chung; C.K.Kim and Y.H.Chung (1996):

Effect of heparine and caffeine on acrosome reaction and protein pattern of korean native cattle sperm in vitro. 8th AAAP Animal Science Congress, Japan, 13-18 October, Vol. 2, Page: 492-493. 
Table 1): Effect of heparin concentrations and incubation periods on seprm viability and arosome reaction percentages in buffaloes $(n=10)$

\begin{tabular}{|c|c|c|c|c|c|c|c|c|}
\hline \multicolumn{3}{|c|}{ Criteria } & \multicolumn{6}{|c|}{ Incubation Time (in hours) } \\
\hline $\begin{array}{c}\text { Heparin } \\
\text { Doses }\end{array}$ & $\begin{array}{c}\text { Sperm } \\
\text { Viability }\end{array}$ & $\mathrm{AR}$ & Ih. & $2 \mathrm{~h}$. & $3 \mathrm{~h}$. & $4 \mathrm{~h}$. & $5 \mathrm{~h}$. & $6 \mathrm{~h}$. \\
\hline $\begin{array}{c}100 \\
\mu \mathrm{g} / \mathrm{ml}\end{array}$ & Alive & $\begin{array}{c}\mathrm{R} . \\
\mathrm{NR} . \\
\mathrm{R} \\
\mathrm{NR}\end{array}$ & $\begin{array}{r}44.6 \pm 1.5 \\
44.3 \pm 1.3 \\
7.0 \pm 1.3 \\
4.2 \pm 1.5\end{array}$ & $\begin{array}{r}36.4 \pm 2.3 \\
47.6 \pm 4.8 \\
12.7 \pm 1.7 \\
3.4 \pm 2.6\end{array}$ & $\begin{array}{r}42.9 \pm 1.0 \\
33.7 \pm 0.7 \\
14.2 \pm 1.4 \\
9.3 \pm 0.4\end{array}$ & $\begin{array}{l}21.4 \pm 0.8 \\
46.5 \pm 0.6 \\
13.0 \pm 1.3 \\
19.2 \pm 0.6\end{array}$ & $\begin{array}{r}27.0 \pm 3.8 \\
43.8 \pm 1.4 \\
19.8 \pm 1.5 \\
8.4 \pm 4.0\end{array}$ & $\begin{array}{l}38.4 \pm 0.4 \\
13.2 \pm 1.7 \\
19.2 \pm 0.5 \\
29.2 \pm 1.1\end{array}$ \\
\hline $\begin{array}{c}200 \\
\mu \mathrm{g} / \mathrm{ml}\end{array}$ & $\begin{array}{l}\text { Alive } \\
\text { Dead }\end{array}$ & $\begin{array}{c}\mathrm{R} \\
\mathrm{NR} . \\
\mathrm{R} . \\
\mathrm{NR}\end{array}$ & $\begin{array}{r}65.8 \pm 0.9 \\
20.5 \pm 1.9 \\
8.3 \pm 1.2 \\
5.4 \pm 1.4\end{array}$ & $\begin{array}{r}65.9 \pm 0.8 \\
16 . .4 \pm 1.4 \\
5.5 \pm 1.2 \\
12.2 \pm 0.8\end{array}$ & $\begin{array}{l}61.3 \pm 6.0 \\
15.5 \pm 0.8 \\
11.8 \pm 1.1 \\
11.4 \pm 6.2\end{array}$ & $\begin{array}{l}52.7 \pm 1.8 \\
16.4 \pm 0.7 \\
12.5 \pm 2.1 \\
18.4 \pm 0.7\end{array}$ & $\begin{array}{l}51.1 \pm 0.9 \\
21.5 \pm 1.3 \\
16.2 \pm 0.7 \\
11.2 \pm 1.6\end{array}$ & $\begin{array}{l}56.6 \pm 0.4 \\
12.1 \pm 0.6 \\
18.5 \pm 0.5 \\
12.8 \pm 0.7\end{array}$ \\
\hline $\begin{array}{c}300 \\
\mu \mathrm{g} / \mathrm{ml}\end{array}$ & Alive & $\begin{array}{c}\text { R. } \\
\text { NR. } \\
\text { R. } \\
\text { NR }\end{array}$ & $\begin{array}{r}52.8 \pm 6.9 \\
34.2 \pm 10.1 \\
7.9 \pm 2.4 \\
5.0 \pm 1.8\end{array}$ & $\begin{array}{r}52.6 \pm 0.5 \\
27.3 \pm 0.4 \\
11.0 \pm 0.6 \\
9.0 \pm 1.1\end{array}$ & $\begin{array}{c}38.8 \pm 0.3 \\
36.1 \pm 0.5 \\
9.4 \pm 0.8 \\
15.7 \pm 0.7\end{array}$ & $\begin{array}{r}60.1 \pm 0.7 \\
15.9 \pm 1.0 \\
15.5 \pm 0.9 \\
8.5 \pm 0.5\end{array}$ & $\begin{array}{c}61.5 \pm 4.9 \\
14.0 \pm 5.0 \\
15.2 \pm 1.3 \\
9.1 \pm 0.7\end{array}$ & $\begin{array}{l}33.8 \pm 2.7 \\
21.5 \pm 1.2 \\
34.1 \pm 1.9 \\
10.5 \pm 2.8\end{array}$ \\
\hline $\begin{array}{c}400 \\
\mu \mathrm{g} / \mathrm{ml}\end{array}$ & Alive & $\begin{array}{c}\mathrm{R} \\
\mathrm{NR} \\
\mathrm{R} \\
\mathrm{NR}\end{array}$ & $\begin{array}{r}55.5 \pm 0.7 \\
13.6 \pm 0.8 \\
25.8 \pm 0.6 \\
5.1 \pm 1.2\end{array}$ & $\begin{array}{r}54.9 \pm 2.5 \\
5.8 \pm 2.2 \\
6.6 \pm 2.9 \\
32.8 \pm 2.1\end{array}$ & $\begin{array}{l}43.9 \pm 0.9 \\
18.4 \pm 0.2 \\
23.2 \pm 1.3 \\
14.5 \pm 0.7\end{array}$ & $\begin{array}{c}34.6 \pm 2.0 \\
22.1 \pm 1.0 \\
37.2 \pm 1.2 \\
5.7 \pm 3.3\end{array}$ & $\begin{array}{r}52.8 \pm 1.1 \\
13.4 \pm 0.5 \\
24.8 \pm 0.9 \\
9.0 \pm 1.7\end{array}$ & $\begin{array}{l}37.7 \pm 1.2 \\
14.3 \pm 1.4 \\
24.3 \pm 1.2 \\
23.8 \pm 2.2\end{array}$ \\
\hline $\begin{array}{c}\text { Zero } \\
\mu \mathrm{g} / \mathrm{ml} \\
\text { Control }\end{array}$ & Alive & $\begin{array}{c}\mathrm{R} . \\
\mathrm{NR} \\
\mathrm{R} . \\
\mathrm{NR}\end{array}$ & $\begin{array}{c}3.1 \pm 0.5^{\circ} \\
89.4 \pm 0.6^{\circ} \\
1.6 \pm 0.9^{\circ} \\
5.9 \pm 1.0^{\circ}\end{array}$ & $\begin{array}{c}3.3 \pm 0.7^{\circ} \\
86.8 \pm 0.9^{\circ} \\
1.5 \pm 0.8^{\circ} \\
8.4 \pm 0.5^{\circ}\end{array}$ & $\begin{array}{r}3.7 \pm 0.2^{\circ} \\
86.3 \pm 1.3^{\circ} \\
2.1 \pm 1.3^{\circ} \\
8.0 \pm 0.7^{\circ}\end{array}$ & $\begin{array}{c}3.7 \pm 0.4^{\circ} \\
86.3 \pm 1.0^{\circ} \\
1.7 \pm 0.7^{\circ} \\
8.3 \pm 0.7^{\circ}\end{array}$ & $\begin{array}{c}5.3 \pm 0.5^{\circ} \\
78.6 \pm 0.9^{\circ} \\
3.6 \pm 0.3^{\circ} \\
12.5 \pm 1.2^{\circ}\end{array}$ & $\begin{array}{c}5.3 \pm 0.7^{\circ} \\
75.6 \pm 1.4^{\circ} \\
4.4 \pm 1.8^{\circ} \\
14.9 \pm 0.9^{\circ}\end{array}$ \\
\hline
\end{tabular}

Mean \pm STd

* Significant $(\mathrm{P}<0.01)$

$\mathrm{AR}=$ Acrosome Reaction

$\mathrm{NR}=$ non Reacted

$\mathrm{R}=$ Reacted 
Table (2): The effect of incubation hours and doses of heparin on alive sperm percentages and accosome reaction (GLM).

\begin{tabular}{|c|c|c|c|c|c|c|c|}
\hline $\begin{array}{l}\text { Incubation } \\
\text { Hours } \\
(n=80)\end{array}$ & $\overline{A R}$ & Alive (\%) & Dead (\%) & $\begin{array}{l}\text { Heparin } \\
\text { Doses } \\
(n=60)\end{array}$ & $\overline{A R}$ & Alive (\%) & Dead (\%) \\
\hline \multirow[t]{2}{*}{1} & nr & 23.97 & 7.61 & 100 & nr & 38.16 & 12.28 \\
\hline & $\tau$ & $50.48^{\wedge}$ & $17.78^{\circ}$ & & r & $35.10^{c}$ & $14.31^{6}$ \\
\hline \multirow[t]{2}{*}{2} & nr & 27.00 & 11.65 & 200 & $\mathrm{nr}$ & 20.39 & 11.90 \\
\hline & : & $52.46^{\wedge}$ & $8.88^{\circ}$ & & r & $55.57^{A}$ & $\underline{12.14^{\wedge}}$ \\
\hline \multirow[t]{2}{*}{3} & nr & 31.13 & 12.94 & 300 & $\mathrm{nr}$ & 24.87 & 9.64 \\
\hline & $\mathrm{r}$ & $42.87^{b}$ & $13.08^{d}$ & & $r$ & $49.94^{\circ}$ & $15.51^{\circ}$ \\
\hline \multirow[t]{2}{*}{4} & $\mathrm{nr}$ & 23.13 & 12.78 & 400 & nr & 14.59 & 15.16 \\
\hline & r & $47.42^{b}$ & $16.68^{\mathrm{E}}$ & & r & $46.55^{\circ}$ & $23.63^{c}$ \\
\hline \multirow[t]{2}{*}{5} & nr & 26.51 & 9.41 & & & & \\
\hline & $r$ & $45.88^{\circ}$ & $17.94^{\mathrm{E}}$ & & & & \\
\hline \multirow[t]{3}{*}{6} & nr & 15.26 & 19.07 & & & & \\
\hline & $r$ & 41.63 & $24.05^{\wedge}$ & & & & \\
\hline & Std Err & \pm 1.26 & \pm 0.67 & SId ET & & \pm 1.02 & \pm 0.79 \\
\hline
\end{tabular}

* L.s.mean

\section{GLM $=$ General Linear Model}

Data with the same letters are non significant, while others with different letters are significant for the same column ( $\mathrm{P}>0.001)$.

Table (3): Sperm motility percentages during incubation after washing in three different buffalo bulls.

\begin{tabular}{|c|c|c|c|c|c|c|c|c|}
\hline \multirow{2}{*}{$\begin{array}{c}\text { Buffalo } \\
\text { Bull } \\
\text { No. }\end{array}$} & \multicolumn{7}{|c|}{ Incubation hours $n=5$} & \multirow[t]{2}{*}{$\begin{array}{l}\text { Total } \\
\mathrm{n}=35\end{array}$} \\
\hline & $0 \mathrm{~h}$. & $1 \mathrm{~h}$. & $2 \mathrm{~h}$. & $3 \mathrm{~h}$. & $4 \mathrm{~h}$. & $5 \mathrm{~h}$. & $6 \mathrm{~h}$. & \\
\hline 1 & $\begin{array}{r}77.2 \pm \\
1.18^{\wedge}\end{array}$ & $\begin{array}{r}75.5 \pm \\
1.15^{\mathrm{A}}\end{array}$ & $\begin{array}{r}77.2 \pm \\
1.18^{\mathrm{A}}\end{array}$ & $\begin{array}{r}77.2 \pm \\
1.18^{\mathrm{A}}\end{array}$ & $\begin{array}{r}77.2 \pm \\
1.18^{\mathrm{A}}\end{array}$ & $\begin{array}{r}77.2 \pm \\
1.18^{\mathrm{A}}\end{array}$ & $\begin{array}{r}77.2 \pm \\
1.18^{\mathrm{A}}\end{array}$ & $\begin{array}{l}77.2 \pm \\
1.18^{\mathrm{A}}\end{array}$ \\
\hline 2 & $\begin{array}{r}76.7 \pm \\
1.18^{A}\end{array}$ & $\begin{array}{l}77.5 \pm \\
1.15^{\mathrm{Ab}}\end{array}$ & $\begin{array}{r}76.7 \pm \\
1.18^{A}\end{array}$ & $\begin{array}{r}76.7 \pm \\
1.18^{\wedge}\end{array}$ & $\begin{array}{r}76.7 \pm \\
1.18^{A}\end{array}$ & $\begin{array}{l}76.7 \pm \\
1.18^{\mathrm{A}}\end{array}$ & $\begin{array}{r}76.7 \pm \\
1.18^{A}\end{array}$ & $\begin{array}{r}76.7 \pm \\
1.18^{A}\end{array}$ \\
\hline 3 & $\begin{array}{l}79.7 \pm \\
1.18^{A}\end{array}$ & $\begin{array}{r}80.5 \pm \\
1.15^{b}\end{array}$ & $\begin{array}{r}79.7 \pm \\
1.18^{A}\end{array}$ & $\begin{array}{r}79.7 \pm \\
1.18^{\wedge}\end{array}$ & $\begin{array}{l}79.7 \pm \\
1.18^{\mathrm{A}}\end{array}$ & $\begin{array}{r}79.7 \pm \\
1.18^{\mathrm{A}}\end{array}$ & $\begin{array}{r}79.7 \pm \\
1.18^{\mathrm{A}}\end{array}$ & $\begin{array}{r}79.7 \pm \\
1.18^{\wedge}\end{array}$ \\
\hline Total & $78.2^{A}$ & $77.8^{A}$ & $77.2^{\wedge}$ & $74.8^{B}$ & $73.0^{B}$ & $69.0^{c}$ & $65.5^{d}$ & \\
\hline
\end{tabular}

Data with the same letters are non significant, while others with different letters are significant for the same column(Between bulls), $(\mathrm{P}<0.01)$.

*Data with the same letters are non significant, while others with different letters are significant for the same row(Between the total for hour). 


\section{Assiut Vet. Med. J. Vol. 38 No. 76. January 1998}

Table (4): The effect of heparin treatment $(200 \mu \mathrm{g} / \mathrm{ml})$ on viability and acrosome reaction of sperm stained with NEG in three different buffalo bulls.

\begin{tabular}{|c|c|c|c|c|c|c|}
\hline \multirow{2}{*}{$\begin{array}{l}\text { Bull } \\
\text { No. }\end{array}$} & \multirow{2}{*}{$\begin{array}{l}\text { Acrosome } \\
\text { Reaction } \\
n=70\end{array}$} & \multirow{2}{*}{$\begin{array}{l}\text { Alive } \\
\text { Mean+S.D }\end{array}$} & Dead & Total alive & Total dead & \multirow[t]{2}{*}{$\mathrm{n}$} \\
\hline & & & Mean \pm S.D & $\begin{array}{l}\text { Ls.mean } \quad \pm \\
\text { std.err }\end{array}$ & $\begin{array}{l}\text { Ls.mean } \\
\text { tstd.err }\end{array}$ & \\
\hline 1 & $\begin{array}{l}\mathrm{NR} \\
\mathrm{R}\end{array}$ & $\begin{array}{l}34.3 \pm 14.6 \\
28.1 \pm 11.9\end{array}$ & $\begin{array}{l}15.1 \pm 3.7 \\
22.3 \pm 8.2\end{array}$ & $31.2 \pm 1.3^{b}$ & $18.7 \pm 0.4^{\mathrm{cb}}$ & 140 \\
\hline 2 & $\begin{array}{l}\mathrm{NR} \\
\mathrm{R}\end{array}$ & $\begin{array}{l}51.6 \pm 17.4 \\
23.8 \pm 14.8\end{array}$ & $\begin{array}{l}11.8 \pm 3.9 \\
12.8 \pm 4.7\end{array}$ & $37.7 \pm 1.3^{A}$ & $12.3 \pm 0.4^{b}$ & 140 \\
\hline 3 & $\begin{array}{l}\mathrm{NR} \\
\mathrm{R}\end{array}$ & $\begin{array}{l}58.7 \pm 20.5 \\
22.8 \pm 13.3\end{array}$ & $\begin{array}{l}10.9 \pm 5.1 \\
7.5 \pm 5.0\end{array}$ & $40.7 \pm 1.3^{A}$ & $9.2 \pm 0.4 \mathrm{~A}$ & 140 \\
\hline
\end{tabular}

\section{$\mathrm{P}>0.001$}

$\mathrm{NR}=$ non reacted $\quad \mathrm{R}=$ Reacted

Data with the same letters are non significant, while others with different letters are significant for the same column(Between bulls), $\mathrm{P}<0.01$

Table (5): Percentages of successful in vitro buffalo oocytes maturation and penetration with the in vitro capacitated buffalo spermatozoa.

\begin{tabular}{|c|c|c|c|c|c|}
\hline \multirow{2}{*}{ Nrial } & $\begin{array}{c}\text { Selected ocytes } \\
\text { No. }\end{array}$ & \multicolumn{2}{|c|}{ Matured oocytes } & \multicolumn{2}{c|}{ Penetration index } \\
\cline { 2 - 6 } & & No & $\%$ & No & $\%$ \\
\hline 1 & 29 & 20 & 68.9 & 2 & 5.0 \\
4 & 21 & 16 & 76.2 & 31.3 \\
5 & 27 & 19 & 70.4 & 3 & 15.8 \\
6 & 25 & 19 & 76.0 & 5 & 26.3 \\
7 & 28 & 20 & 71.4 & 9 & 45.0 \\
\hline Total & 38 & 29 & 76.3 & 13 & 44.8 \\
\hline
\end{tabular}




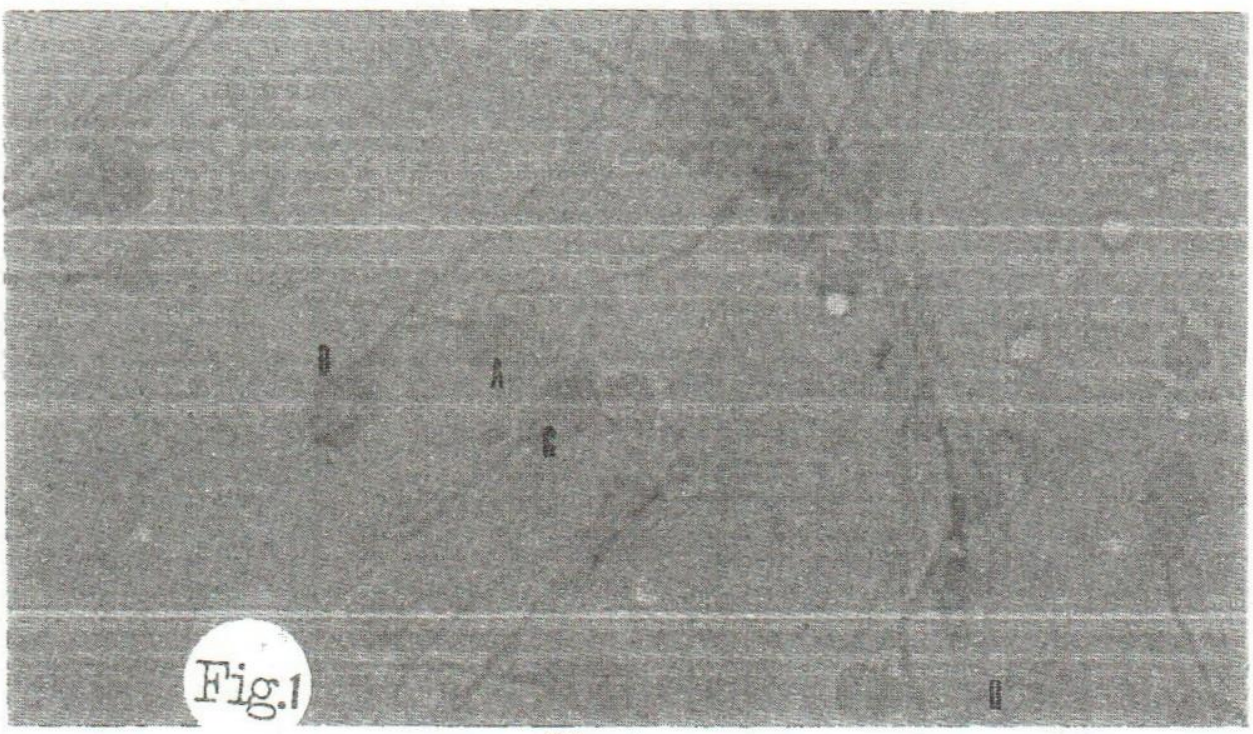

Fig. 1:

In vitro capacitated buffalo sperms stained with NEG stain that shows the following:

a-Alive reacted.

b- Dead non reacted.

c-Alive non reacted. d-Dead reacted.

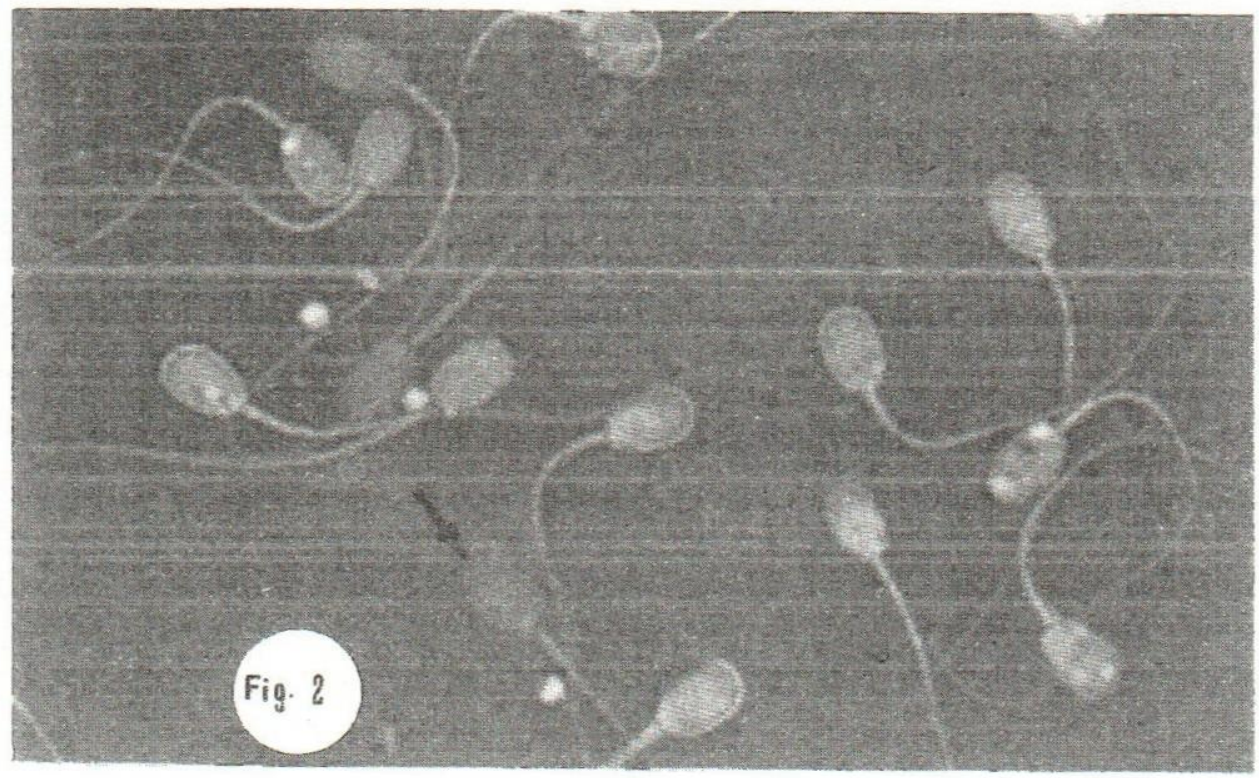

Fig. 2

In vitro capacitated buffalo sperms stained with NE stain that shows dead sperms stained red in colour. 


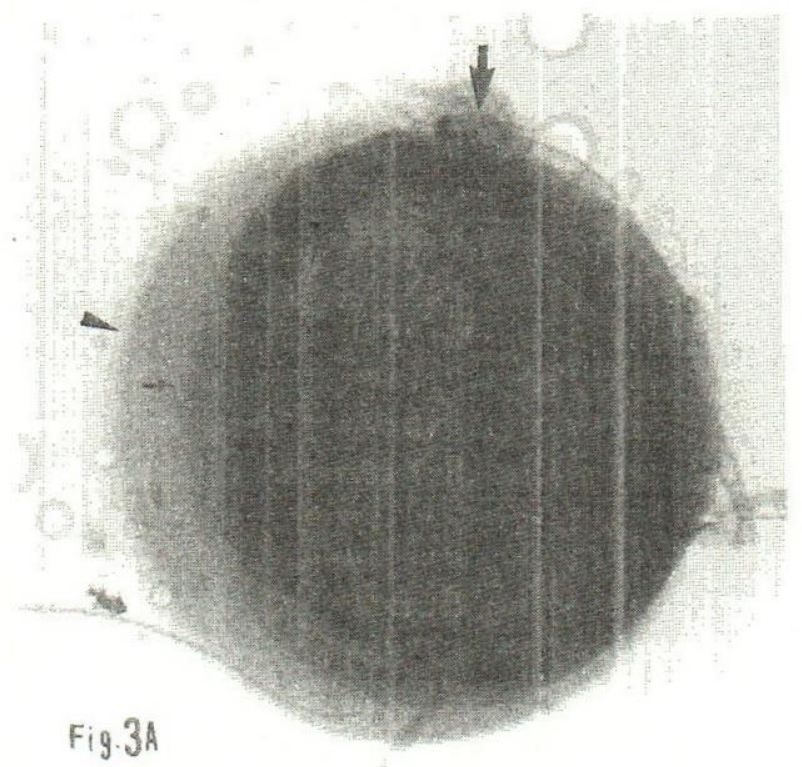

Fig. $3 a$

Showing in vitro fertlized buffalo ovum with pronuclei (pointed by arrows) and sperm head (pointed by head arrow)

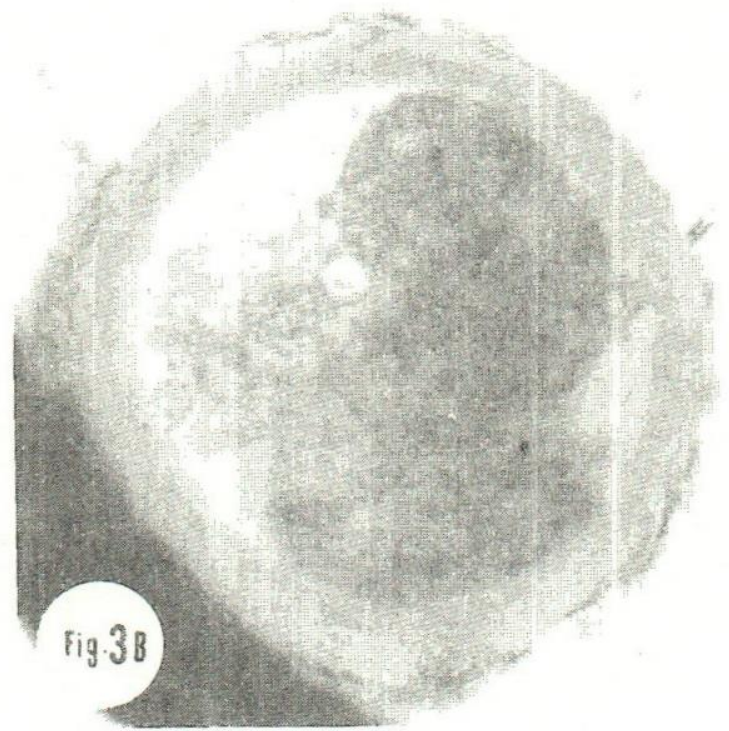

Fig. 3b

Showing in vitro cleaved buffalo ovum" Two cell stage". 
